\title{
Implementasi Naïve Bayessian dengan Laplacian Smoothing untuk Peminatan dan Lintas Minat Siswa SMAN 5 Pamekasan
}

\author{
Indah Listiowarni ${ }^{[1]}$, Nilam Ramadhani ${ }^{[2]}$ \\ Teknik Informatika, Universitas Madura ${ }^{[1],[2]}$ \\ J1.Panglegur KM 3.5, Pamekasan, Jawa Timur \\ indah@unira.ac.id ${ }^{[1]}$, nilam_ramadhani@yahoo.com ${ }^{[2]}$
}

\begin{abstract}
Abstrak - Kurikulum 2013 memiliki beberapa perubahan dasar dari kurikulum sebelumnya, salah satunya adalah penyaluran dan penempatan siswa pada program peminatan. Setelah dilakukan klasifikasi peminatan, siswa akan diklasifikasikan lagi menggunakan nilai tes, yang disebut sebagai Lintas Minat Siswa. Penelitian ini berkonsentrasi untuk menerapkan metode Naive Bayessian pada sebuah sistem untuk menanggulangi permasalahan rumitnya proses klasifikasi dua tingkatan dan banyaknya data setiap tahunnya.Naive Bayes merupakan salah satu metode machine learning yang menggunakan perhitungan probabilitas, dan memggunakan laplacian smoothing untuk menghindari hasil akhir bernilai 0 . Nilai perhitungan accuracy dan error rate pada 720 data training dengan pengambilan 5 kali jumlah data testing yang berbeda menggunakan naive bayessian dan laplacian smoothing, didapat nilai accuracy : $92,11 \%$ dan nilai error rate : $7,02 \%$
\end{abstract}

Kata Kunci-naive bayes, peminatan, lintas minat siswa, laplacian smoothing, data mining, klasifikasi

\section{PENDAHULUAN}

Kurikulum 2013 merupakan kurikulum baru yang dijadikan acuan oleh beberapa SMA/MA/SMK atau sekolah yang sederajat, termasuk SMAN 5 Pamekasan. Kurikulum 2013 memiliki beberapa perubahan dasar dari kurikulum sebelumnya, salah satunya adalah peyaluran dan penempatan siswa pada program peminatan . Peminatan siswa adalah sebuah proses klasifikasi siswa pada sebuah bidang mata pelajaran sesuai dengan minat dan kemampuan siswa itu sendiri. Program peminatan siswa tersebut tidak lagi dilakukan saat siswa menginjak kelas XI melainkan mulai diklasifikasikan sejak siswa menjadi siswa baru (kelas X) di SMAN 5 Pamekasan, sehingga siswa diharapkan mampu menguasai bidang yang diinginkannya sejak mulai masuk SMA. Setelah siswa diklasifikasikan sesuai minat dan kemampuannya, semua siswa diberi kesempatan untuk mempelajari mata pelajaran di luar bidang minatnya yang diklasifikasikan lagi menggunakan nilai tes, yang disebut sebagai Lintas Minat Siswa yang akan dilakukan pada tahun pertama semester kedua, setelah Peminatan Siswa[1].
Peminatan dan Lintas Minat Siswa SMAN 5 Pamekasan diklasifikasi oleh tim BK yang terdiri dari 3 orang guru dan menangani lebih dari 300 orang siswa setiap tahunnya, jumlah data yang lumayan banyak dan proses klasifikasi yang terbilang rumit, akan banyak memakan banyak waktu dan tenaga. Sehingga dibutuhkan sebuah sistem yang bisa membantu tim guru BK (Bimbingan Konseling) dalam hal klasifikasi data nilai siswa, dan keakuratan data pada hasil akhir klasifikasi Peminatan dan Lintas Siswa.

Proses klasifikasi pada sebuah data tidak luput dengan penggunaan sebuah metode. Naive Bayes classifier merupakan metode yang paling banyak digunakan untuk proses klasifikasi. Naive Bayes classifier menggunakan teorema Bayes yaitu memprediksi peluang di masa depan berdasarkan pengalaman di masa sebelumnya. Ciri utama dari naive bayes classifier adalah asumsi yang kuat akan independensi dari masing-masing kondisi, artinya naive bayes classifier memiliki variabel yang independen. Dengan menerapkan Naive Bayes pada sebuah data terkadang juga menyebabkan missclassification jika data training hanya sedikit atau data-nya tidak kaya sehingga data testing tidak ditemukan pada data training, dan menyebabkan hasil probabilitas bernilai 0 (zero) dan menyebabkan error pada proses klasifikasi .

Kekurangan naive bayes classifier dapat diminimalisir dengan menggunakan metode smoothing, selain itu beberapa penelitian sebelumnya membuktikan bahwa metode smoothing dapat meningkatkan perfomance dari naive bayes classifier. Pada penelitian ini digunakan metode smoothing yaitu laplacian smoothing, atau yang biasa disebut add-one smoothing [2].

Penelitian yang berfokus pada klasifikasi peminatan pada siswa tingkat SMA, juga pernah dilakukan dalam penelitian lain, yaitu klasifikasi penjurusan siswa pada SMAN 1 Pontianak dengan menggunakan metode Algoritma C4.5[3], selanjutnya pada SMAN 2 Semarang dengan membandingkan Metode Regresi Logistik Biner dan Multivariate Adaptive Regression Spline [4] 


\section{METODE PENELITIAN}

Metode penelitian digunakan untuk menjelaskan dan memberikan gambaran tentang penelitian yang akan digunakan, dataset yang akan digunakan, pembagian class pada setiap klasifikasi (peminatan dan lintas minat), alur sistem, metode yang digunakan dan pembahasan tahapan preprocessing yang dilakukan.

\section{A. Dataset}

Data yang digunakan dalam penelitian ini merupakan sebuah kesatuan data yang didapat dari instansi terkait yaitu SMAN 5 Pamekasan yang dijadikan tempat penelitian dan menambang data, Data yang diperlukan untuk proses penggalian data klasifikasi peminatan dan lintas minat siswa adalah berupa data siswa yang terdiri dari berbagai atribut yaitu nama siswa, nilai raport, nilai UNBK, IQ siswa, dan nilai tes pendukung lainnya.

Kumpulan data yang didapat akan digunakan untuk proses pengklasifikasian data siswa untuk mengetahui apakah siswa A diklasifikasikan sebagai siswa yang dipetakan dalam peminatan kelas IPA atau IPS, dan yang selanjutnya akan diklasifikasikan kembali menjadi kelas IPA ekonomi dan IPA geografi(kebumian), sedangkan pada Lintas Minat IPS akan diklasifikasikan menjadi kelas IPS Kimia dan kelas IPS Fisika. Pada penelitian ini digunakan data siswa pada tahun 2018 untuk data testing dengan jumlah 180 data, dan data training diambil dari data siswa selama 4 tahun, mulai dari tahun 2014 hingga tahun 2017 dengan jumlah total 720 data siswa

\section{B. Pre-Processing}

Sebelum melakukan proses klasifikasi peminatan dan lintas minat siswa dengan menggunakan naive bayessian dengan laplace smoothing, perlu dilakukan pre-processing data untuk menyiapkan data[5]. Tahapan pre-processing yang dilakukan pada penelitian ini terdiri dari 3 tahapan pada setiap dataset yaitu data cleaning, data selection dan terakhir data transformation, dijelaskan pada gambar 1 .

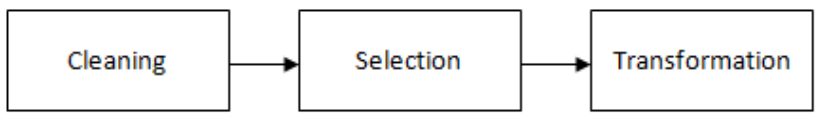

Gambar 1. Alur Pre-processing data

Data cleaning dilakukan pada record data yang tidak sesuai, seperti penghapusan karakter yang tidak diperlukan, mengisi data yang kosong (penyesuaian isi) dan pembulatan nilai pada atribut rata-rata rapor. Data selection dilakukan untuk memilih atribut yang akan digunakan pada proses selanjutnya dan membuang yang tidak diperlukan, seperti pada dataset peminatan siswa, atribut yang dihapus adalah atribut nama, jenis kelamin dan atribut rekomendasi BK, dan atribut pada dataset lintas minat siswa juga mengalamai penghapusan atribut nama. Data transformation yaitu tahapan pre-processing untuk mengubah isi dan melakukan perubahan atribut, perubahan pada dataset setelah dilakukan transformation adalah sebagai berikut :

\section{Peminatan siswa}

Data diubah atau digabung ke dalam format yang sesuai untuk diproses dalam data mining, Objek pada dataset yang awalnya berupa non-angka, akan dinotasikan menjadi angka, dalam hal ini akan terjadi pada atribut Prestasi Akademik. Tabel 1 menjelaskan bagaimana seharusnya data tersebut bertransformasi dari non-angka menjadi angka

Tabel 1. Aturan Kepemilikan Sertifikat Akademik

\begin{tabular}{|l|l|}
\hline Range Nilai Tes & Keterangan \\
\hline 1 & Ada \\
\hline 0 & Tidak Ada \\
\hline
\end{tabular}

Selain itu, data set juga akan mengalami perubahan pada beberapa atribut, seperti pada satuan nilai pada rata-rata nilai raport SMP (Sekolah Menengah Pertama) akan diubah menjadi atribut lain mengingat syarat peminatan siswa yang digunakan oleh SMA Negeri 5 Pamekasan.

MIPA : atribut gabungan dari rata-rata mata pelajaran Matematika dan IPA

$\frac{\text { Matematika }+I P A}{2}=$ MIPA

MIPS : atribut gabungan dari rata-rata mata pelajaran Matematika dan IPS

$\frac{\text { Matematika+IPS }}{2}=$ MIPS

Rata-rata : atribut gabungan dari rata-rata mata pelajaran Matematika, IPA, IPS, Bahasa Indonesia, dan Bahasa Inggris

$\frac{M a t+I P A+I P S+B I N+B I G}{5}=$ rata-rata

Rata-rata UNBK : atribut gabungan dari semua mata pelajaran UNBK, yaitu Matematika, IPA, Bahasa Indonesia, dan Bahasa Inggris

$\frac{\text { Mat+IPA+BIN }+ \text { BIG }}{4}=$ rata UNBK

Sehingga, dengan menggunakan persamaan (1)-(4) didapatkan data hasil transformasi/pengubahan isi atribut dari dataset sebelumnya. Persamaan (1)-(4) digunakan untuk mengubah dan menyesuaikan nilai pada tahap klasifikasi peminatan siswa, dimana MIPA adalah Matematika-IPA, MIPS adalah Matematika-IPS, IPA adalah Ilmu Pengetahuan Alam, IPS adalah Ilmu Pengetahuan Sosial, BIN adalah Bahasa Indonesia, BIG adalah Bahasa Inggris dan UNBK adalah Ujian Nasional Berbasis Komputer, hasil data transformation dapat terlihat seperti pada tabel 2.

ISSN : :2301-7988

E-ISSN : 2581-0588

DOI : $10.32736 /$ sisfokom.v8i2.652 
Tabel 2. Hasil Data Transformation Peminatan Siswa (Data Training)

\begin{tabular}{|l|l|l|l|l|l|l|l|}
\hline NISN & $\begin{array}{l}\text { MI } \\
\text { PA }\end{array}$ & $\begin{array}{c}\text { MI } \\
\text { PS }\end{array}$ & $\begin{array}{c}\text { Rata } \\
\text { Rata }\end{array}$ & $\begin{array}{c}\text { Rata- } \\
\text { rata } \\
\text { UN } \\
\text { BK }\end{array}$ & IQ & prestasi & Kelas \\
\hline $\begin{array}{l}0007203 \\
313\end{array}$ & 90 & 91 & 88 & 84 & $\begin{array}{l}11 \\
0\end{array}$ & 0 & IPA \\
\hline $\begin{array}{l}0001685 \\
099\end{array}$ & 89 & 90 & 87 & 91 & $\begin{array}{l}10 \\
5\end{array}$ & 1 & IPA \\
\hline $\begin{array}{l}9986741 \\
555\end{array}$ & 88 & 86 & 86 & 87 & $\begin{array}{l}10 \\
0\end{array}$ & 1 & IPA \\
\hline
\end{tabular}

\section{Lintas minat siswa}

Untuk data set Lintas Minat juga perlu melewati proses transformation atau perubahan atribut sebelum masuk ke proses selanjutnya,

MIPA : atribut gabungan dari rata-rata raport SMP pada mata pelajaran Matematika dan IPA, atribut MIPA digunakan untuk siswa yang mengikuti lintas minat IPA, untuk me-transformasi nilai Matematika dan IPA menjadi MIPA dapat menggunakan persamaan (5).

$$
\frac{\text { Matematika+IPA }}{2}=\text { MIPA }
$$

MIPS : atribut gabungan dari rata-rata raport SMP pada mata pelajaran Matematika dan IPS, untuk me-transformasi nilai Matematika dan IPS menjadi MIPS dapat menggunakan persamaan (6).

$$
\frac{\text { Matematika+IPS }}{2}=\text { MIPS }
$$

Mafis : atribut gabungan (rata-rata)nilai raport semester I Matematika, fisika, dan biologi, untuk me-transformasi nilai Matematika, Biologi dan Fisika menjadi Mafis dapat menggunakan persamaan (7).

$$
\frac{\text { Matematika }+ \text { biologi+fisika }}{3}=\text { mafis }
$$

Makim : atribut gabungan (rata-rata)nilai raport semester I Matematika, kimia, dan biologi, , untuk metransformasi nilai Matematika, Biologi dan Kimia menjadi Makim dapat menggunakan persamaan (8)

$$
\frac{\text { Matematika }+ \text { biologi }+ \text { kimia }}{3}=\text { makim }
$$

Matgeo : atribut gabungan (rata-rata)nilai raport semester I Matematika, ekonomu, dan geografi, , untuk metransformasi nilai Matematika, Ekonomi dan Geografi menjadi Matgeo dapat menggunakan persamaan (9)

$$
\frac{\text { Matematika+ekonomi+geografi }}{3}=\text { matgeo }
$$

Matsos : atribut gabungan (rata-rata)nilai raport semester I Matematika, ekonomi, dan sosiologi, , untuk metransformasi nilai Matematika, ekonomi dan sosiologi menjadi Matsos dapat menggunakan persamaan (10)

$$
\frac{\text { Matematika+ekonomi }+ \text { sosiologi }}{3}=\text { matsos }
$$

Dengan menggunakan persamaan (5)-(10) didapatkan Hasil data transformation pada lintas minat siswa dapat dilihat pada tabel 3 untuk lintas minat IPA (Ilmu Pengetahuan Alam) dan tabel 4 untuk lintas minat IPS (Ilmu Pengetahuan Sosial)

Tabel 3. hasil data transformation lintas minat IPA

\begin{tabular}{|c|c|c|c|c|c|}
\hline NISN & $\begin{array}{c}\text { MI } \\
\text { PA }\end{array}$ & $\begin{array}{c}\text { MI } \\
\text { PS }\end{array}$ & $\begin{array}{c}\text { MAT } \\
\text { GEO }\end{array}$ & $\begin{array}{c}\text { MATS } \\
\text { OSIO }\end{array}$ & Minat \\
\hline $\begin{array}{l}9995967 \\
299\end{array}$ & 88 & 89 & 77 & 77 & Sosiologi \\
\hline $\begin{array}{l}0008465 \\
630\end{array}$ & 88 & 89 & 75 & 76 & Geografi \\
\hline $\begin{array}{l}9983381 \\
489\end{array}$ & 87 & 86 & 76 & 75 & Sosiologi \\
\hline
\end{tabular}

Tabel 4. hasil data transformation lintas minat IPS

\begin{tabular}{|c|c|c|c|c|c|}
\hline NISN & $\begin{array}{c}\text { MI } \\
\text { PA }\end{array}$ & $\begin{array}{c}\text { MI } \\
\text { PS }\end{array}$ & $\begin{array}{c}\text { MAT } \\
\text { KIM }\end{array}$ & $\begin{array}{c}\text { MAT } \\
\text { FIS }\end{array}$ & Minat \\
\hline $\begin{array}{c}999596289 \\
9\end{array}$ & 75 & 76 & 71 & 73 & Fisika \\
\hline $\begin{array}{c}000846563 \\
1\end{array}$ & 73 & 74 & 68 & 69 & Fisika \\
\hline $\begin{array}{c}998338159 \\
0\end{array}$ & 73 & 76 & 73 & 72 & $\begin{array}{c}\text { Bio- } \\
\text { kim }\end{array}$ \\
\hline
\end{tabular}

\section{Metode}

Proses penggalian data (data mining) adalah proses penentuan Pilihan Kelas yang tepat bagi seorang siswa dengan perhitungan didasarkan pada nilai mata pelajaran yang ada dan sesuai dengan probabilitas yang terbesar.

Pada proses penggalian data ini menggunakan Metode Naïve Bayessian Classification dengan Laplacian smoothing dengan beberapa tahapan, yaitu sebagai berikut [6]:

1. Menentukan Data Tes

2. Menentukan Nilai $\mathrm{Ci}$ dan Nilai $X$

3. Menghitung $\mathrm{P}(\mathrm{X} \mid \mathrm{Ci}), \mathrm{i}=1,2$ untuk setiap kelas

4. Perhitungan Naïve Bayes dengan Laplacian Smoothing

5. Menentukan Nilai Probabilitas terbesar.

6. Hasil klasifikasi

Proses penggalian data dengan menggunakan Metode Naïve Bayessian Classification dengan Laplacian smoothing, dapat digambarkan dengan alur proses pada Gambar 2. 


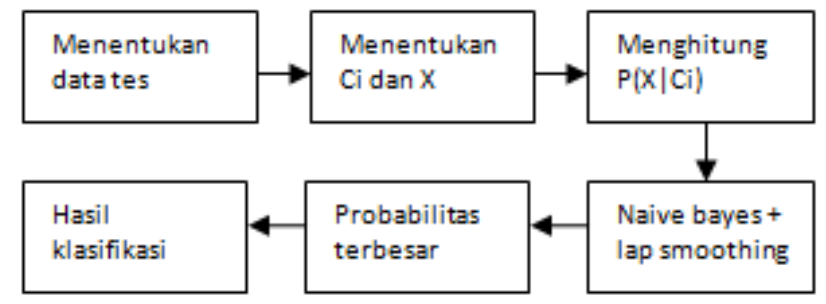

Gambar 2. proses mining

Naive bayes classifier, merupakan algoritma klasifikasi berdasarkan penerapan teorema bayes dengan asumsi independen yang kuat, output dari classifier berupa nilai probabilitas yang menunjukkan sebuah dokumen atau data harus diklasifikasikan atau dikelompokkan, sesuai nilai probabalitas tertinggi yang dihasilkan [7], nilai probabilitas kemunculan data dapat diketahui dengan menggunakan persamaan (11)

$$
\mathrm{P}(\mathrm{H} \mid \mathrm{X})=\frac{\mathrm{P}(\mathrm{X} \mid \mathrm{H}) \mathrm{P}(\mathrm{H})}{\mathrm{P}(\mathrm{X})}
$$

Metode smoothing merupakan metode untuk menghindari hasil klasifikasi bernilai 0 dikarenakan data testing tidak ditemukan pada data training. Pada penelitian ini digunakan metode laplace smoothing, yaitu metode smoothing yang paling sederhana karena hanya menambahkan angka 1, tapi metode laplace smoothing memiliki perfomance yang cukup baik dibandingkan dengan metode smoothing lainnya[8], pada penerapan text atau numerik. Salah satunya pada perbandingan smoothing untuk pengkategorian soal ujian [2], sebagai penerapan pada data text (text mining).

$$
P(H \mid X)=\frac{P(X \mid H) P(H)+1}{P(X)+|V|}
$$

dimana $|\mathrm{V}|$ merupakan jumlah class yang digunakan, $\mathrm{P}(\mathrm{X})$ merupakan peluang data sampel yang diamati [9].

\section{HASIL DAN PEMBAHASAN}

Proses penggalian data dengan menggunakan metode Naive Bayessian Classification dengan Laplacian Smoothing, mengikuti proses alur pada gambar 2 dimulai dengan menentukan data tes hingga terbentuk proses klasifikasi pada setiap tujuan klasifikasi, yaitu klasifikasi peminatan siswa dan lintas minat siswa

Tahap evaluasi juga diperlukan untuk mengukur perfomance naive bayessian menggunakan laplacian smoothing, menggunakan perhitungan accuracy dan error rate [10] pada hasil klasifikasi peminatan siswa.

$$
\begin{aligned}
& \text { accuracy }=\frac{T P+T N}{T P+T N+F P+F N} \\
& \text { error rate }=\frac{F P+F N}{F P+F N+T P+T N}
\end{aligned}
$$

Evaluasi dilakukan dengan pengambilan 5 kali jumlah data testing yang berbeda terhadap 720 data training, untuk mengetahui pengaruh jumlah data tes, terhadap hasil klasifikasi. Tabel 5 menjelaskan hasil accuracy dan error rate untuk setiap pengambilan jumlah data tes yang berbeda, sekaligus memperlihatkan jumlah rata-rata accuracy dan error rate, dengan menggunakan persamaan (13) maka didapatkan nilai accuracy dan persamaan (14) digunakan untuk mengetahui nilai error rate

Tabel 5. hasil evaluasi pada hasil klasifikasi peminatan siswa

\begin{tabular}{|r|r|r|r|}
\hline \multicolumn{1}{c|}{$\begin{array}{c}\text { Jumlah } \\
\text { data } \\
\text { testing }\end{array}$} & $\begin{array}{c}\text { Jumlah } \\
\text { Data } \\
\text { Training }\end{array}$ & $\begin{array}{c}\text { Accuracy } \\
(\%)\end{array}$ & $\begin{array}{c}\text { Error Rate } \\
(\%)\end{array}$ \\
\hline 35 & 720 & 90,33 & 6,86 \\
\hline 60 & 720 & 96 & 4 \\
\hline 80 & 720 & 90 & 8,5 \\
\hline 100 & 720 & 92 & 7,77 \\
\hline 180 & 720 & 92,22 & 7,026 \\
\hline & & 92,11 & \\
\hline
\end{tabular}

Setelah melakukan perhitungan data mining dan didapatkan sebuah hasil berupa klasifikasi, sebuah sistem akan diuji keakuratan data yang dihasilkan, dan kemungkinan error rate yang muncul. Dalam hal ini sistem akan di evaluasi menggunakan perhitungan confusion matrix, dengan begitu nilai akurasi dan error dapat diketahui.

Seperti yang terlihat pada tabel 5, Jumlah dan macam data testing yang digunakan dalam proses mining mempengaruhi hasil yang didapat dari perhitungan akurasi dan error rate, pada gambar 4.21 diketahui hasil akurasi adalah 93,33\%dan error rate 6,66\%, hasil tersebut didapat dari hasil proses mining yang terdiri dari 15 data testing dan 100 data training, kemudian hasil yang berbeda didapatkan ketika sistem mengeksekusi data testing dengan jumlah yang berbeda

Berikut adalah hasil tampilan implementasi naive bayes pada data siswa untuk mengklasifikasikan peminatan dan lintas minat siswa. Mulai dari data training, data testing, hasil hingga evaluasi.

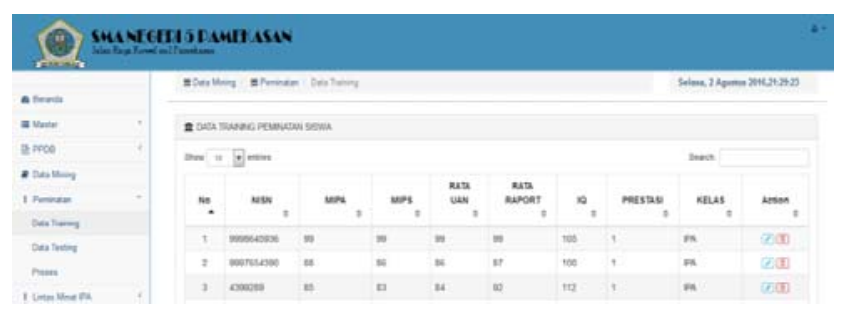

Gambar 6. DataTraining Peminatan siswa

ISSN : 2301-7988

E-ISSN : 2581-0588

DOI $: 10.32736 /$ sisfokom.v8i2.652 


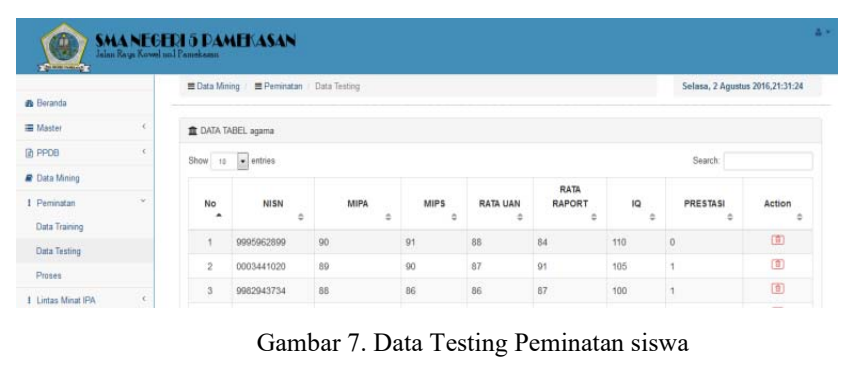

Gambar 6 dan gambar 7 secara berurutan merupakan tampilan halaman pengolahan data training dan data testing. Pada halaman data training dan data testing, terdapat beberapa menu yang dapat digunakan yaitu menambah dan menghapus data. Data testing yang digunakan pada penelitian ini (gambar 7) merupakan data testing dan bukan merupakan bagian dari data training.

Pre-processing data secara otomatis dilakukan di dalam sistem, sehingga memudahkan user, hingga didapatkan hasil mining yang dapat dilihat rinci perhitungannya menggunakan naive bayes dan laplace smoothing pada gambar 8.

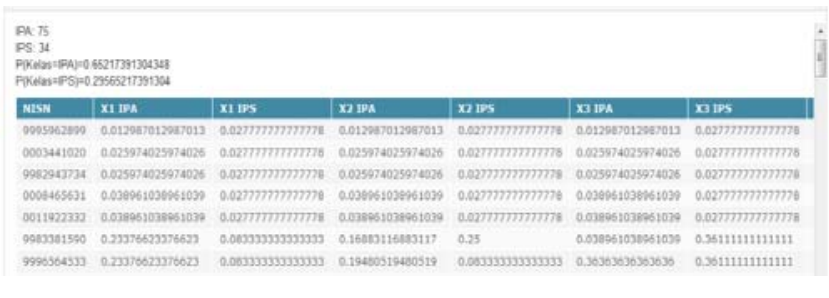

Gambar 8. Hasil klasifikasi Peminatan siswa

Selanjutnya, tampilan pada gambar 9 akan diringkas lagi tampilan nya (menampilkan data yang dibutuhkan untuk proses mining selanjutnya atau kebutuhan pelaporan/berkas), agar memudahkan pengguna untuk mengetahui hasil klasifikasi yang direkomendasikan, pada gambar 8 .

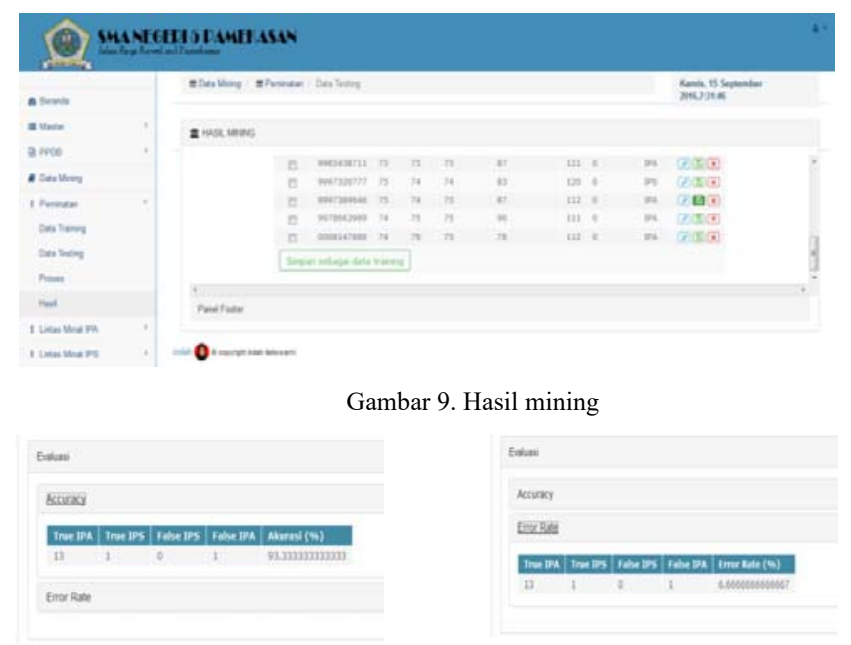

Gambar 10 hasil evaluasi
Tampilan pada gambar 10 merupakan hasil evaluasi yang berguna untuk mengetahui sejauh mana tingkat keakuratan hasil klasifikasi sesuai dengan data asli, sehingga dapat meyakinkan pihak SMAN 5 Pamekasan untuk menggunakan hasil klasifikasi.

\section{KESIMPULAN}

Metode Laplace smoothing berhasil mengurangi kemungkinan kegagalan klasifikasi, karena bisa mencegah hasil klasifikasi bernilai 0, dari hasil perhitungan klasifikasi dengan menggunakan naive bayes dengan laplacian smoothing nilai perhitungan accuracy dan error rate menggunakan confusion matrix pada 720 data training dengan pengambilan 5 kali jumlah data testing yang berbeda, didapat nilai accuracy : $92,11 \%$ dan nilai error rate : $7,02 \%$. Sehingga hasil klasifikasi dapat dijadikan pertimbangan penentuan kelas peminatan dan lintas minat siswa SMAN 5 Pamekasan

Penelitian selanjutnya bisa dengan menambahkan fitur perbandingan untuk metode smoothing lainnya selain dengan metode laplace smoothing.

\section{DAFTAR PUSTAKA}

[1] Kementerian Pendidikan Dan Kebudayaan RI, "Pedoman Peminatan Peserta Didik," pp. 1-74, 2013.

[2] I. Listiowarni and E. R. Setyaningsih, "Analisis Kinerja Smoothing pada Naive Bayes untuk Pengkategorian Soal Ujian," J. Teknol. Manaj. Inform., vol. 4, 2018.

[3] B. Novianti, T. Rismawan, and S. Bahri, "Implementasi Data Mining Dengan Algoritma C4.5 Untuk Penjurusan Siswa (Studi Kasus: Sma Negeri 1 Pontianak)," J. Coding, Sist. Komput. Untan, vol. 04, no. 3, pp. 75-84, 2016.

[4] R. Binadari, Y. Wilandari, and Suparti, "Perbandingan Metode Regresi Logistik Biner dan Multivariate Adaptive Regression Spline (MARS) pada Peminatan Jurusan SMA (Studi Kasus SMA Negeri 2 Semarang)," J. Gaussian, vol. 4, no. 4, pp. 987-996, 2015.

[5] S. Garcia, "Effectiveness of Data preprocessing for data mining," Int. J. Curr. Eng. Technol., vol. 4, no. 5, pp. 3480-3483, 2014.

[6] B. Said, "DATA SMS CENTER BUPATI PAMEKASAN MENGGUNAKAN NAÏVE BAYES DAN WINNOWING," J. LINK, vol. 26, no. 2, pp. 1$5,2017$.

[7] E. Prasetyowati and N. Ramadhani, "Sistem Evaluasi Dan Klasifikasi Kinerja Akademik Mahasiswa Universitas Madura Menggunakan Naive Bayes Dengan Dirichlet Smoothing," JUTI J. Ilm. Teknol. Inf., vol. 16, no. 2, p. 192, 2018. 
[8] R. A. Ramadhani, F. Indriani, and D. T. Nugrahadi, "Comparison of Naive Bayes smoothing methods for Twitter sentiment analysis," 2016 Int. Conf. Adv. Comput. Sci. Inf. Syst. ICACSIS 2016, no. October 2016, pp. 287-292, 2017.

[9] V. Cherian and M. S. Bindu, "Heart Disease Prediction Using Naïve Bayes Algorithm and Laplace Smoothing Technique," Int. J. Comput. Sci. Trends Technol., vol. 5, no. 2, pp. 68-73, 2017.

[10] S. Rachmatullah and A. P. Wijaya, "Rekomendasi Disposisi Surat dengan Metode Naïve Bayes Pada Arsip Surat di Kantor Bakorwil Kabupaten Pamekasan," DoubleClick J. Comput. Inf. Technol., vol. 2, no. 2, pp. 50-59, 2019. 